\title{
Understanding the Relationship between HRM Practices and Organization Performance in HDFC Bank
}

\author{
Dr. Rafia Gulzar \\ Human Resource Department, College of Business \\ Dar Al-Uloom (Riyadh) Saudi Arabia
}

\begin{abstract}
The main purpose of this paper is to understand the relationship between HRM Practices and organizational performance and to evaluate the perceptions of managers and non- managers on HRM practices in the context of HDFC Bank. The data was randomly collected from 24 managers and 72 subordinates using a self-administered questionnaire. The research study empirically evaluated the nine HRM practices (General climate, OCTAPACE Culture, Selection Process, Job Definition, Career Planning, Employee Participation, Performance Appraisal, Training and Development and compensation). The study showed that there is direct relationship between HRM practices and organizational performance. Finally, this research study depicts the limitations, suggestions and future research directions.
\end{abstract}

Key Words: PAS, Performance Appraisal, OCTAPACE and HDFC Bank.

\section{INTRODUCTION}

Banking industry, as such, is the single most important constituents of the service sector, which is very crucial for the economic development of any country. Indian banking industry is passing through a very critical phase and confronted with very serious challenges both from within and outside. Opening up of economy, entry of foreign banks, establishment of new generation private sector banks, unprecedented pace of automation, global competition, communication revolution, demand for improved customer services, fluctuating rates of interest, incurring of heavy losses, marketing a wide range of products and product lines, restructuring of organizations, absorption and amalgamations etc. All these challenges in economics, social, cultural, technological, psychological environment have important implications on the HRM practices being followed in the banking industry as well as on the performance of the banks. All the HRM practices like recruitment, training and development, compensation and rewards, performance appraisal, promotion and empowerment, sharing of decisions, job security and security of monetary and non- monetary benefits, welfare measures and separations in the form of lay-offs, retrenchment \& golden handshake have come under tremendous pressure. As a result, the performance of the banking sector has been affected very seriously as far as customer retention, profitability, business turnover, market share, retention of products and product lines, satisfactory customer services and returns on investment are concerned.

Over the past 40 years \& above, human resources are considered as unique \& most valuable assets of an organization. The successful management of an organization's human resources can cause a rise or fall of an organization. It is an exciting, dynamic and challenging task, especially during modern time when the world has become one large global village and economies are in a state of flux \& ever changing dynamics. Short supply of talented resources and growing expectations of the modern day worker have further increased the complexity of the human resource function. Despite specific human resource functions/activities being the responsibility of the human resource department, the actual management of human resources 
is the responsibility of every manager in an organization. There is an increasing demand and pressure to sustain and improve the organizational performance through efficient and motivated workforce.

In this paper, an attempt has been made to understand the relationship between HRM practices and organizational performance in HDFC Bank.

\section{Research Objectives}

The study focused on the following objectives:

1. To address the relationship between HRM practices and organizational performance,

2. To identify the impact of HRM practices on organizational performance

\section{HYPOTHESIS}

To give the proper direction to the study, a set of following working hypothesis has been developed:

H1: HRM practices have significant association with organizational performance.

H2: HRM practices have significant impact on organizational performance.

\section{Independent Variable}

The study looked at the following Independent variables that contribute significantly to organizational performance: General climate, OCTAPACE Culture, Selection Process, Job Definition, Career Planning, Employee Participation, Performance Appraisal, Training and Development and compensation.

\section{Dependent Variable}

The dependent variable was perception of employees towards organizations performance.

\section{REVIEW OF LITERATURE}

Human Resource Management is very important for banks because banking is a service industry. Research suggest that service quality is increasingly recognized as a crucial factor that determines the level of success of any business (Parasuraman et al., 1988). Banking sector in this case cannot be an exception. Level of quality service is widely used to evaluate the performance of banking services (Cowling and Newman, 1995). The banks realize that customers will be loyal if they receive higher values than competitors (Dawes and Swailes, 1999) while on the other hand, banks in return can earn higher profits if they are able to position themselves better than their competitors within the specific market segments (Davies et al., 1995). People management and risk management are two key challenges banks are facing. It has become big threat as well as opportunity for banks to manage its workforce and risks to find out the success in the business of banking. Skilled \& efficient manpower is responsible for efficient \& effective risk management. Banking is "People Business" means it start from people (employees) and ends with people (customers). Researchers stated that human resources are people that are employed in an organisation to carry out their daily duties in exchange for wages, salaries or rewards (Denisi and Griffin, 2005). Human resources are ways and means to achieving competitive advantage because of its nature of converting the other resources (money, machine, methods and material) into output (product/service). A competitor may imitate resources like capital \& latest technology but not human resource.

According to Khatri (1999), people are the single most important factors providing adaptability \& flexibility to organizations. Rundle (1997), argues that we need to keep in mind that people are the adaptive mechanism that will determine how the organization will respond 
to the competitive environment. Many scholars have reasoned that managing people is not as easy as managing capital or technology (Barney, 1991; Lado and Wilson, 1994). However those organizations that have understood and learned to manage their employees/HR well would have better chance to overcome others in the long run because acquiring and finally deploying and managing employees/HR effectively is important and takes much longer way (Wright et al., 1994). On one hand, human resource management is the formal system that includes philosophy, policies, and practices in an organisation to ensure that it effectively utilizes the knowledge, skill, abilities, and other characteristics of the employees to achieve the organisational goals (Pynes, 2009). Proper management of human resources can provide a competitive advantage for organisations to compete in their respective industries. Human resource practices such as the recruitment and selection, training and development, compensation and benefits, retention, evaluation and promotion of employees, and labor management relations are the practices that have always been carried out and have become key elements in an organisation. It is important for the organisation to recruit the right people to fill up available vacancies in order to attain the standard needed in delivering the required quality of services and products (Hayes and Ninemeie, 2009).

\section{Impact of HRM Practices on Organizational Performance}

A lot of researchers are trying to establish a relationship between HRM and the performance of an organization have taken a micro approach, investigating every single HRM practices such as staffing, training, goal-setting, compensation and effects of those practices on organizational outcomes is shown in Exhibit 2.3 as under: 
Exhibit 2.3: Empirical Studies of HRM Practices and Organizational Performance

\begin{tabular}{|c|c|c|c|}
\hline Researcher & HRM Practices & Dependent variable & Finding \\
\hline $\begin{array}{l}\text { Russell, Terborg } \\
\text { \& Powers } \\
(1985)\end{array}$ & $\begin{array}{l}\text { Training, organizational } \\
\text { support }\end{array}$ & Store performance & $\begin{array}{l}\text { Training was positively } \\
\text { correlated with store } \\
\text { performance. }\end{array}$ \\
\hline $\begin{array}{l}\text { Balkin, } \\
\text { GomezMejia } \\
(1987)\end{array}$ & Compensation & - & $\begin{array}{l}\text { Incentive-based reward } \\
\text { systems were more } \\
\text { effective in growth } \\
\text { stage \& high-tech } \\
\text { companies. }\end{array}$ \\
\hline $\begin{array}{l}\text { Jackson, Schuler \& } \\
\text { Rivero (1989) }\end{array}$ & $\begin{array}{l}\text { Appraisal compensation, } \\
\text { training, employment } \\
\text { security }\end{array}$ & - & $\begin{array}{l}\text { Significant association } \\
\text { between firms pursuing } \\
\text { high and low innovation } \\
\text { strategy and HR } \\
\text { practices. }\end{array}$ \\
\hline $\begin{array}{l}\text { Gerhart \& } \\
\text { Milkovich } \\
\text { (1990) }\end{array}$ & $\begin{array}{l}\text { Contingent pay and base } \\
\text { pay }\end{array}$ & $\begin{array}{l}\text { Firm financial } \\
\text { performance }\end{array}$ & $\begin{array}{l}\text { Positive relationship } \\
\text { between contingent pay } \\
\text { and financial } \\
\text { performance of firms. }\end{array}$ \\
\hline $\begin{array}{l}\text { Terpstra \& } \\
\text { Rozell (1993) }\end{array}$ & Staffing practices & $\begin{array}{l}\text { Annual profit, profit } \\
\text { growth, sales growth } \\
\& \quad \text { overall } \\
\text { performance }\end{array}$ & $\begin{array}{l}\text { Positive, significant } \\
\text { effect of extensive } \\
\text { staffing practices on } \\
\text { annual profit, profit } \\
\text { growth, and overall } \\
\text { performance. }\end{array}$ \\
\hline Bartel (1994) & Employee Training & Labor productivity & $\begin{array}{l}\text { Formal employee } \\
\text { training eliminates } \\
\text { productivity gap. }\end{array}$ \\
\hline
\end{tabular}

Russell, Terborg and Powers (1985), worked on the relationship between training, organizational support and performance of organizations. They considered a sample of sixtytwo retail stores. Their study utilized data obtained from a company developed attitude survey. The findings provided evidence that both training and organizational support was positively and significantly related to store performance. In a study conducted by Balkin and GomezMejia (1987), on compensation, it was revealed that incentive-based reward systems were more effective in growth stage and in high-tech companies. Jackson, Schuler and Rivero (1989), worked on the variation in performance appraisal, compensation, and training and development programs within different strategic setting. Results revealed from the survey responses showed organizations utilizing an innovation strategy as a means of differentiation versus other organizations were less likely to use incentive compensation, more likely to offer 
employment security, likely to provide more total hours of training and more likely to offer employees training related to both skills needed currently \& skills required in the future.

Gerhart \& Milkovich (1990), studied impacts of contingent pay and base pay on a company's performance. They also examined the determinants of pay mix in an effort to distinguish the extent to which pay mix decisions vary after controlling employee investments in human capital, personal characteristics and job characteristics. Their work revealed that support for variation in pay mix even after controlling of these factors. They also found a lot of relationships between pay mix and industry, company size \& company's financial performance. Terpstra \& Rozell (1993), also studied effects of widespread staffing practices with company performance as their direct dependent variable. The staffing practices investigated were follow-up studies on recruitment sources, validation of studies on selection instruments, structured/standardized interviews, mental ability tests and biological information blanks or weighted application blanks. The study found that the extent of use of these staffing practices varied by industry and organizational size. Performance measures examined in the study were annual profit, profit growth, sales growth and overall performance. The results revealed a positive \& significant effect of extensive staffing practices on all the above factors namely annual profit, profit growth, sales growth and overall performance. Bartel (1994), also made use of training as an independent variable \& labor productivity as dependent variable and found that the implementation of training programs for employees was directly related to labor productivity gains.

The studies mentioned above provide examples of the growing interests in the effects of specific HRM practices on organizational outcomes. Becker \& Gerhart (1996), have concluded that HR systems are path dependent. However, HRM practices \& policies don't exist in organizations in isolation. As a result, a growing body of work has turned toward examination of these systems of HRM practices in an attempt to determine the true effect of HRM on organizational performance.

HRM practices improve organizational performance. Rondeau and Wager (2001), examined the co-relation between HRM practices, workplace climate \& perceptions of organizational performance, in a large sample of Canadian nursing homes. The study found that nursing homes, which had implemented more 'progressive' HRM practices, had a general tendency to perform better on a number of valued organizational outcomes. Chand \& Katou (2007), conducted a study to investigate if some characteristics of hotels affect organizational performance in the hotel industry in India \& to examine if some HRM systems affect organizational performance. Their study revealed that hotel performance is positively associated with hotel category, type of hotel \& hotel performance is directly related to HRM systems of recruitment \& selection, manpower planning, job design, training \& development, quality circle \& pay system. Joseph \& Dai (2009), in their studies found that there is a direct relation between HRM practices \& organizational performance that alignment of HRM is also a driver for organization's performance.

The analysis carried out by Nayaab et al. (2011), revealed HRM practices contribute to the enhanced banks performance. Additionally, the result indicated that HRM practices like training, employee participation in decision making were directly proportional to overall performance of the bank. Further, Osmann et al. (2011), reported in his studies that the effectiveness of implementing HRM practices in an organization has a significant impact towards its performance. The findings also show that HRM practices directly affect almost 50\% of a company's performance. Huselid (1995), conducted a study to report the link between systems of High Performance work practices and company's performance and found that these practices have an impact on intermediate employee outcomes (turnover and productivity), 
short \& long term measures of corporate financial performance. Hyde et al. (2008), studied the impact of HRM practices on an organization's profitability and concluded that little support for a positive relationship between HRM practices and organization profitability. Carl (2000), examined the relationship between human resource management practices followed by performance of 101 foreign-owned subsidiaries in Russia. The results of the study provide support for the assertion that investments in HRM practices can substantially contribute a company to perform better.

In order to understand the impact of HRM practices on organizational performance the following nine variables were taken into consideration:

\section{General Climate}

The general climate is important for HRM practices if it has to be implemented effectively. The general climate is an amalgamation of commitment of top management and line management as well as supportive personnel policies with the positive attitude for development. The general climate is a cognitive interpretation of the organizational situation that has been labeled psychological climate which represents how work environments are cognitively appraised and represented in terms of their meanings and significance for individual employees in organizations.

\section{OCTOPACE Culture}

The essence of the HRD climate can be measured by the importance that is given to the development of OCTAPACE culture in an organization. The term has been created by Professor T.V. Rao. The items like openness, confrontation, trust, authenticity, pro-activity, autonomy, collaboration and experimentation are valued and promoted in the OCTAPACE culture of organizations. Studies conducted by (Rohmetra, 1998; Kumar and Patnaik, 2002; Kumar, 1997; Bhardwaj and Mishra 2002; Mishra, Dhar and Dhar, 1999; Alphonsa, 2000; Rao and Abraham, 1999) shows that the culture of OCTAPACE values is absorbed in the culture of the many organizations to a good or moderate degree. The continuous development of human resources is direct result of the OCTAPACE culture.

\section{Selection Process}

Selection is the process of choosing from the pool of potential employees available for particular jobs in terms of qualified job and organisation requirements. Organisation requirements will include the need to take account of the expectations of existing employees, whether for example, the new employee will find acceptance with existing employees. According to Tim (1995), selection is the assessment of candidates for vacant jobs and the choice of most suitable people. Selection is the oldest function of public personnel administration (Shafritz, Russell and Borick, 2007).

\section{Job Definition}

Job definition is the written format of duties and tasks a single worker is expected to perform (Tracey, 1998). Defining task, authority and systems is facilitated by job definition and hence system are organized and integrated at individual job level and across organization units. Job definition envisages both job description and job specification. It clarifies various responsibilities, duties, working condition and expected skills of a worker performing that particular job (Qureshi and Ramay, 2006). It is necessary for managing employees in organisations. When employees are clear about their tasks and duties they can very easily achieve personal as well as organizational objectives. Job description is "a document which describes major duties, functions, and authority assigned to a position, and the relationship 
between the position and other positions in the organization or department" (Tracey, 1998) and task is defined as "unit of work, a task is created whenever human effort, physical or mental is exerted to achieve a specific purpose" (Shafritz, 1985). Job description mainly describes an employee's responsibilities and duties needed to be performed regarding certain job, while Job specification describes the knowledge, qualification and competencies required to perform a particular job.

\section{Career Planning}

In human resource management, career planning aims to identify needs, aspirations and opportunities for individuals' career and the implementation of developing human resources programs to support that career. According to Manolescu (2003), career planning is a continuous process for an individual to develop his own occupational concept as a result of skills or abilities, needs, motivations and aspiration. Career planning is a systematic and comprehensive process of targeting career development, implementing strategies, self assessment, analysis of opportunities and evaluation of results. Career planning process involves both the organization and the individual responsibility. Therefore, the individuals must identify their aspirations and abilities, and through assessment and counseling to understand their training and developmental needs. The organization needs to identify its needs and opportunities, to plan its employees and to ensure they possess necessary information and appropriate training for career development.

\section{Employee Participation}

Participation is a process which allows employees to exert some influence over their work and the conditions under which they work (Heller, Pusic, trauss and Wilpert, 1998) or alternatively, as a process in which influence on decision making is shared between hierarchical superiors and their subordinates (Wagner and Gooding, 1987). Newstrom and Davis (2004), stated participation as a mental and emotional involvement of people in group situations that encourages them to contribute to group goals and share responsibility for them. It is social processes by which people become self involved in an organization and want to see it work successfully. Mac Gregor (1960), contended that workers participation involves creating opportunity under suitable condition for people to influence the decisions that affect them. It is a special case of delegation in which the subordinate gains control, and has greater freedom of choice in matters of bridging the communication gap between the management and workers. This serves to create a sense of ownership and belonging among the workers, as well as conducive environment in which the worker will voluntarily contribute to management's efforts.

\section{Performance Appraisal}

Performance appraisal (PA) consists of a framework of planned goals, standards and competence requirements and plays an important role in integrating the individual's needs with the organizational needs (Saraswathi, 2010). It is a formal management system that provides for the evaluation of the quality of an individual's performance in an organization (Yousef, 2000). Hussain-Ali and Opatha (2008), stated that performance appraisal is perceived degree to which performance appraisal system has attributes those are right for fair and accurate evaluation of employee job performance. They argue that the attributes comprise nine features such as PA objectives; PA policies; PA criteria and standard; PA form and procedure; training of appraisers; feedback discussion; procedure for ensuring accurate implementation; make decisions and store them and review and renewal. Ali and Akter (2011), stated that employee performance appraisal is subject of great interest in most organizations. There are several reasons behind this. First reason is performance appraisal decisions have effects and consequences on workers compensation and recognition (Bartol and Locke, 2000; Millward et al., 2000). Second important reason is, performance appraisal is important for the 
development of strategic human resources, which looks at employees as an organizational tool for an organization to survive in competitive and turbulent situations (Ahmad and Spice, 2000). Strong evidence shows that performance appraisal has positive association with performance. Hanley (2005), stated that developmental purpose of performance appraisal is more productive in influencing organizational performance. Brown and Heywood (2005), noted that performance appraisal system has positive association with improved productivity of organizations. Lee and Lee (2007), investigated that effective performance appraisal system improves productivity and quality

\section{Training}

In this competitive world, training plays an important role in the competent and challenging format of business. Training is the nerve that suffices the need of fluent and smooth functioning of work which helps in enhancing the quality of work life of employees and organizational performance too. According to Armstrong, (2001) "Training is systematic development of the knowledge, skills and attitudes required by an individual to perform adequately a given task or job". Flippo,(1984) "Training is the act of increasing knowledge and skills of an employee for doing a particular job." Aswathappa (2000) stated that the term 'training' indicates the process involved in improving the aptitudes, skills and abilities of the employees to perform specific jobs. Training helps in updating old talents and developing new ones. 'Successful candidates placed on the jobs need training to perform their duties effectively'. The principal objective of training is to make sure the availability of a skilled and willing workforce to the organization. In addition to that, there are four other objectives: Individual, Organizational, Functional, and Social

\section{Compensation}

Compensation is an integral part of human resource management which helps in motivating the employees and improving organizational effectiveness. According to Bob (2011), compensation processes are based on compensation philosophies and strategies and contain arrangement in the shape of policies and strategies, guiding principles, structures and procedures which are devised and managed to provide and maintain appropriate types and levels of pay, benefits and other forms of compensation. Pearce (2010), stated that compensation implies having a compensation structure in which the employees who perform better are paid more than the average performing employees. Armstrong and Brown (2005), postulate that compensation management is an integral part of HRM approach for managing people and as such it supports the achievement of business objectives. Harrison and Liska (2010), in their study posit that reward is the centre piece of the employment contract after all it is the main reason why people work. This includes all types of rewards, both intrinsic and extrinsic, that are received as a result of employment by the organization.

\section{SAMPLE SIZE}

The total sample taken was 33, out of which 8 were managers and 24 were subordinates.

\section{Selection of the sample organization}

The banking organization under study was Housing Development Finance Corporation Limited (HDFC) Bank. The Housing Development Finance Corporation Limited (HDFC) was amongst the first to receive an 'in principle' approval from the Reserve Bank of India (RBI) to set up a bank in the private sector, as part of the RBI's liberalization of the Indian Banking Industry in 1994. The bank was incorporated in August 1994 in the name of 'HDFC Bank Limited', with its 
registered office in Mumbai, India. HDFC Bank commenced operations as a Scheduled Commercial Bank in January 1995.

HDFC is India's premier housing finance company and enjoys an impeccable track record in India as well as in international markets. Since its inception in 1977, the Corporation has maintained a consistent and healthy growth in its operations to remain the market leader in mortgages. Its outstanding loan portfolio covers well over a million dwelling units. HDFC has developed significant expertise in retail mortgage loans to different market segments and also has a large corporate client base for its housing related credit facilities. With its experience in the financial markets, a strong market reputation, large shareholder base and unique consumer franchise, HDFC was ideally positioned to promote a bank in the Indian environment.

HDFC Bank began operations in 1995 with a simple mission: to be a "World Class Indian Bank." We realized that only a single minded focus on product quality and service excellence would help us get there.

\section{DATA ANALYSIS AND INTERPRETATION \\ Employees view's on HRM variables in HDFC Bank}

The overall survey results of table 1.1 indicates that the mean values and percentage to mean score ranges between $2.50(37.50 \%)$ and $4.50(87.50 \%)$ in case of managers of HDFC bank. The table 5.24 reveals that the mean value and percentage of mean score ranges between 2.50 $(37.50 \%)$ and $4.40(76.0 \%)$ in case of subordinates of HDFC bank. It is imperative to note that higher mean values or higher percentage of mean scores linked across the variables HRM indicates that these variables are perceived to be superior and effective and lower mean values or lower percentage of mean scores across the managers and subordinates have poor opinion about the effectiveness of HRM variables. To continue with the same, the table 1.1 also depicts that the perception of managers in the HDFC bank towards various components of HRM. It can be interpreted that only 35 out of 52 statements have crossed $60 \%$ level of satisfaction among the managerial staff of HDFC bank rest are less than $60 \%$. The table 1.2 depicts the perception of subordinates of HDFC bank towards the various components of HRM. it can be interpreted that only 12 out of 52 statements have crossed $60 \%$ level of satisfaction and rest are below $60 \%$. It reveals that managers are having more favorable perception towards the existing HRM practices in the HDFC bank than subordinates. 
Gulzar, R. (2017). Understanding The Relationship between HRM Practices and Organization Performance in HDFC Bank. Archives of Business Research, 5(3), 53-69.

Table 1.1: Perceived View of HDFC Managers on HRM practices

\begin{tabular}{|c|c|c|c|}
\hline \multirow[t]{2}{*}{ Statements } & \multicolumn{3}{|c|}{ HDFC Managers ( $\mathrm{N}=24)$} \\
\hline & Mean & Mean score & Std. Deviation \\
\hline GC1 & 2.75 & 43.75 & 1.165 \\
\hline GC2 & 3.25 & 56.25 & 1.035 \\
\hline GC3 & 4.00 & 75.00 & 1.309 \\
\hline GC4 & 3.38 & 59.50 & 1.302 \\
\hline GC5 & 3.38 & 59.50 & 1.188 \\
\hline GC6 & 3.75 & 68.75 & 1.282 \\
\hline GC7 & 3.38 & 59.50 & 1.061 \\
\hline OC1 & 2.75 & 43.75 & 0.707 \\
\hline $\mathrm{OC} 2$ & 3.50 & 62.50 & 0.756 \\
\hline OC3 & 3.50 & 62.50 & 0.926 \\
\hline OC4 & 3.13 & 53.25 & 1.356 \\
\hline OC5 & 3.50 & 62.50 & 0.756 \\
\hline OC6 & 4.13 & 78.25 & 0.991 \\
\hline OC7 & 4.00 & 75.00 & 0.535 \\
\hline S1 & 3.87 & 71.75 & 0.641 \\
\hline S2 & 4.13 & 78.25 & 0.641 \\
\hline S3 & 4.00 & 75.00 & 0.756 \\
\hline S4 & 4.13 & 78.25 & 0.991 \\
\hline S5 & 4.50 & 87.50 & 0.756 \\
\hline S6 & 4.13 & 78.25 & 0.641 \\
\hline JD1 & 3.88 & 72.00 & 1.246 \\
\hline JD2 & 3.88 & 72.00 & 0.991 \\
\hline JD3 & 4.00 & 75.00 & 0.756 \\
\hline JD4 & 2.88 & 47.00 & 1.356 \\
\hline CP1 & 3.75 & 68.75 & 1.165 \\
\hline CP2 & 3.75 & 68.75 & 0.707 \\
\hline CP3 & 3.38 & 59.50 & 0.518 \\
\hline $\mathrm{CP} 4$ & 3.25 & 56.25 & 1.165 \\
\hline CP5 & 3.50 & 62.50 & 1.414 \\
\hline CP6 & 4.25 & 81.25 & 0.707 \\
\hline CP7 & 3.63 & 65.75 & 0.916 \\
\hline EP1 & 2.50 & 37.50 & 0.756 \\
\hline EP2 & 3.13 & 53.25 & 0.641 \\
\hline EP3 & 3.50 & 62.50 & 0.756 \\
\hline PA1 & 3.75 & 68.75 & 0.886 \\
\hline PA2 & 3.75 & 68.75 & 0.707 \\
\hline PA3 & 3.50 & 62.50 & 1.069 \\
\hline PA4 & 3.13 & 53.25 & 1.246 \\
\hline PA5 & 3.75 & 68.75 & 0.886 \\
\hline PA6 & 3.75 & 68.75 & 0.886 \\
\hline PA7 & 4.13 & 78.25 & 0.991 \\
\hline T1 & 3.88 & 72.00 & 0.991 \\
\hline $\mathrm{T} 2$ & 4.38 & 84.50 & 0.744 \\
\hline T3 & 3.25 & 56.25 & 1.035 \\
\hline T4 & 4.25 & 81.25 & 0.463 \\
\hline T5 & 3.50 & 62.50 & 0.756 \\
\hline T6 & 3.63 & 65.75 & 1.408 \\
\hline C1 & 3.87 & 71.75 & 0.354 \\
\hline C2 & 3.75 & 68.75 & 1.282 \\
\hline C3 & 3.13 & 53.25 & 1.246 \\
\hline $\mathrm{C} 4$ & 3.25 & 56.25 & 1.389 \\
\hline C5 & 3.13 & 53.25 & 1.126 \\
\hline Total & 3.61 & 65.49 & \\
\hline
\end{tabular}


Table 1.2 Perceived View of HDFC subordinates on HRM practices

\begin{tabular}{|c|c|c|c|}
\hline \multirow[t]{2}{*}{ Statements } & \multicolumn{3}{|c|}{ HDFC Subordinates(N=72) } \\
\hline & Mean score & $\%$ of Mean score & Std. Deviation \\
\hline GC1 & 2.50 & 37.50 & 1.063 \\
\hline GC2 & 3.04 & 51.00 & 1.301 \\
\hline GC3 & 3.04 & 51.00 & 1.122 \\
\hline GC4 & 3.29 & 57.25 & 1.042 \\
\hline GC5 & 3.25 & 56.25 & 1.113 \\
\hline GC6 & 3.04 & 51.00 & 0.999 \\
\hline GC7 & 3.08 & 52.00 & 1.248 \\
\hline OC1 & 3.00 & 50.00 & 1.022 \\
\hline OC2 & 3.33 & 58.25 & 1.239 \\
\hline OC3 & 3.21 & 55.25 & 1.062 \\
\hline OC4 & 3.21 & 55.25 & 1.141 \\
\hline 0C5 & 3.42 & 60.50 & 1.349 \\
\hline OC6 & 3.13 & 53.25 & 1.393 \\
\hline OC7 & 3.67 & 66.75 & 1.274 \\
\hline S1 & 3.25 & 56.25 & 1.152 \\
\hline S2 & 3.33 & 58.25 & 1.239 \\
\hline S3 & 3.33 & 58.25 & 1.239 \\
\hline S4 & 3.33 & 58.25 & 1.308 \\
\hline S5 & 3.67 & 66.75 & 1.204 \\
\hline S6 & 3.08 & 52.00 & 1.283 \\
\hline JD1 & 3.42 & 60.50 & 1.381 \\
\hline JD2 & 3.50 & 62.50 & 1.383 \\
\hline JD3 & 3.83 & 70.75 & 1.007 \\
\hline JD4 & 3.29 & 57.25 & 0.955 \\
\hline CP1 & 3.04 & 51.00 & 1.197 \\
\hline CP2 & 3.33 & 58.25 & 1.167 \\
\hline CP3 & 3.21 & 55.25 & 1.250 \\
\hline $\mathrm{CP} 4$ & 2.92 & 48.00 & 0.974 \\
\hline CP5 & 3.29 & 57.25 & 1.197 \\
\hline CP6 & 3.00 & 50.00 & 1.216 \\
\hline CP7 & 3.21 & 55.25 & 1.215 \\
\hline EP1 & 2.33 & 33.25 & 1.090 \\
\hline EP2 & 3.13 & 53.25 & 1.035 \\
\hline EP3 & 3.37 & 59.25 & 1.245 \\
\hline PA1 & 2.92 & 48.00 & 1.283 \\
\hline PA2 & 3.29 & 57.25 & 1.042 \\
\hline PA3 & 3.00 & 50.00 & 1.063 \\
\hline PA4 & 2.79 & 44.75 & 1.062 \\
\hline PA5 & 3.58 & 64.50 & 1.381 \\
\hline PA6 & 3.38 & 59.50 & 1.013 \\
\hline PA7 & 3.21 & 55.25 & 1.141 \\
\hline $\mathrm{T} 1$ & 3.75 & 68.75 & 0.847 \\
\hline T2 & 3.83 & 70.75 & 0.761 \\
\hline T3 & 3.21 & 55.25 & 0.884 \\
\hline $\mathrm{T} 4$ & 3.58 & 64.50 & 0.881 \\
\hline T5 & 4.04 & 76.00 & 0.690 \\
\hline T6 & 3.79 & 69.75 & 1.103 \\
\hline C1 & 3.25 & 56.25 & 1.152 \\
\hline $\mathrm{C} 2$ & 3.04 & 51.00 & 1.197 \\
\hline C3 & 2.96 & 49.00 & 0.955 \\
\hline C4 & 3.17 & 54.25 & 1.049 \\
\hline $\mathrm{C} 5$ & 2.88 & 47.00 & 1.035 \\
\hline Total & 3.24 & 56.12 & \\
\hline
\end{tabular}




\section{Spearman's Correlation Coefficient}

A lot of research has been conducted throughout the world to study the correlation between HRM practices and organizational performance although most of the research has been conducted in the U.S.A, yet many research studies on the subject are coming from United Kingdom. Research on this important subject is picking up in developing countries also. Research studies reveals that the relationship between HRM practices and organizational performance is positive simply there is a positive correlation between two.

Keeping the background in view, the present study has been conducted to study the relationship between HRM practices perceived organizational performance in the banking industry in India. The correlation coefficients clearly present the results of the current study. The inter correlation among different HRM practices and different measures of Organizational performance is studied, as there are glaring differences in so far results of the study are concerned. Same has been analyzed in the following paragraphs.

From table 1.3, it is clear that managers of HDFC shows positive correlation between General climate and other HRM variables with the highest positive correlation(0.497) between General climate and employee participation and is statistically significant with p-value 0.013 and lowest positive correlation (0.114) between general climate and selection. The negative correlation is only between employee participation and Career planning $(-0.094)$ and between compensation and employee participation $(-0.117)$ and is statistically non-significant. The overall highest positive correlation of 0.676 exists between Selection and job definition and is statistically significant with $p$-value $\geq 0.0001$. Likewise, higher level of positive correlation exists between various HRM Practices such as 0.582(Performance Appraisal and Job Definition), 0.569 (OCTAPACE culture and employee participation), 0.532(between compensation and Performance Appraisal), 0.485 (Performance Appraisal and career planning),0.430 (OCTAPACE culture and Job Definition). The lower degree of positive correlation exists between various dimensions of HRM practices such as 0.038 (Selection and Training), 0.064(Career Planning and OCTAPACE culture), 0.067(Training and Employee Participation), 0.078(Training and OCTAPACE culture)

Table 1.3: Correlation coefficients among HRM practices in the managers of HDFC bank

\begin{tabular}{|c|c|c|c|c|c|c|c|c|c|c|}
\hline Variables & & GC & OC & $\mathbf{S}$ & JD & $\mathbf{C P}$ & EP & PA & $\mathbf{T}$ & $\mathbf{C}$ \\
\hline \multirow[t]{2}{*}{$\begin{array}{l}\text { General } \\
\text { climate(GC) }\end{array}$} & $\begin{array}{l}\text { Correlation } \\
\text { Coefficient }\end{array}$ & 1.000 & & & & & & & & \\
\hline & P-Value & & & & & & & & & \\
\hline \multirow[t]{2}{*}{$\begin{array}{l}\text { OCTAPACE } \\
\text { Culture(OC) }\end{array}$} & $\begin{array}{l}\text { Correlation } \\
\text { Coefficient } \\
\end{array}$ & 0.125 & 1.000 & & & & & & & \\
\hline & P-Value & 0.357 & & & & & & & & \\
\hline \multirow[t]{2}{*}{ Selection(S) } & $\begin{array}{l}\text { Correlation } \\
\text { Coefficient }\end{array}$ & 0.114 & 0.252 & 1.000 & & & & & & \\
\hline & P-Value & 0.439 & 0.085 & & & & & & & \\
\hline \multirow[t]{2}{*}{ Job Definition(JD) } & $\begin{array}{l}\text { Correlation } \\
\text { Coefficient }\end{array}$ & 0.133 & $0.430^{*}$ & $0.676^{* *}$ & 1.000 & & & & & \\
\hline & P-Value & 0.469 & 0.014 & 0.000 & & & & & & \\
\hline \multirow[t]{2}{*}{$\begin{array}{l}\text { Career } \\
\text { Planning(CP) }\end{array}$} & $\begin{array}{l}\text { Correlation } \\
\text { Coefficient }\end{array}$ & $0.409^{* *}$ & 0.064 & 0.238 & 0.300 & 1.000 & & & & \\
\hline & P-Value & 0.002 & 0.637 & 0.104 & 0.096 & & & & & \\
\hline \multirow[t]{2}{*}{$\begin{array}{l}\text { Employee } \\
\text { Participation(EP) }\end{array}$} & $\begin{array}{l}\text { Correlation } \\
\text { Coefficient } \\
\end{array}$ & $0.497^{*}$ & $0.569^{* *}$ & 0.203 & 0.287 & -.094 & 1.000 & & & \\
\hline & P-Value & 0.013 & 0.004 & 0.342 & 0.174 & 0.662 & & & & \\
\hline \multirow[t]{2}{*}{$\begin{array}{l}\text { Performance } \\
\text { Appraisal(PA) }\end{array}$} & $\begin{array}{l}\text { Correlation } \\
\text { Coefficient } \\
\end{array}$ & $0.362^{* *}$ & 0.173 & $0.369^{* *}$ & $0.582^{* *}$ & $0.485^{* *}$ & 0.234 & 1.000 & & \\
\hline & P-Value & 0.006 & 0.201 & 0.010 & 0.000 & 0.000 & 0.270 & & & \\
\hline \multirow[t]{2}{*}{ Training(T) } & $\begin{array}{l}\text { Correlation } \\
\text { Coefficient } \\
\end{array}$ & 0.217 & 0.078 & 0.038 & 0.120 & $0.289^{*}$ & 0.067 & 0.236 & 1.000 & \\
\hline & P-Value & 0.139 & 0.598 & 0.797 & 0.513 & 0.046 & 0.757 & 0.107 & . & \\
\hline \multirow[t]{2}{*}{ Compensation(c) } & $\begin{array}{l}\text { Correlation } \\
\text { Coefficient } \\
\end{array}$ & 0.128 & -.214 & 0.157 & 0.154 & 0.119 & -.117 & $0.532^{* *}$ & 0.158 & 1.000 \\
\hline & P-Value & 0.431 & 0.186 & 0.335 & 0.400 & 0.463 & 0.587 & 0.000 & 0.330 & \\
\hline
\end{tabular}


The results in the' table 1.4 shows that the highest association of 0.618 between Performance Appraisal and Selection among subordinates, followed by various positive correlation of 0.536 between Career Planning and Selection, 0.508 between Performance Appraisal and Career Planning, 0.479 between Compensation and Selection, 0.417 between Compensation and Career Planning, 0.414 between Selection and General Climate, 0.398 between Performance Appraisal and Job Definition, 0.368 between Compensation and Performance Appraisal and so on and are statistically significant. A large number of positive correlations are sufficient proof that HRM practices are positively related although the degree of association varies considerably.

Table 1.4: Correlation coefficients among HRM practices of the subordinates in HDFC Bank

\begin{tabular}{|c|c|c|c|c|c|c|c|c|c|c|}
\hline Variables & & GC & OC & S & JD & CP & EP & PA & $T$ & C \\
\hline \multirow[t]{2}{*}{ General climate(GC) } & $\begin{array}{l}\text { Correlation } \\
\text { Coefficient }\end{array}$ & 1.000 & & & & & & & & \\
\hline & P-Value & & & & & & & & & \\
\hline \multirow[t]{2}{*}{$\begin{array}{l}\text { OCTAPACE } \\
\text { Culture(OC) }\end{array}$} & $\begin{array}{l}\text { Correlation } \\
\text { Coefficient }\end{array}$ & $0.268^{* *}$ & 1.000 & & & & & & & \\
\hline & P-Value & 0.000 & & & & & & & & \\
\hline \multirow[t]{2}{*}{ Selection(S) } & $\begin{array}{l}\text { Correlation } \\
\text { Coefficient }\end{array}$ & $0.414^{* *}$ & $0.200^{*}$ & 1.000 & & & & & & \\
\hline & P-Value & 0.000 & 0.016 & & & & & & & \\
\hline \multirow[t]{2}{*}{ Job Definition(JD) } & $\begin{array}{l}\text { Correlation } \\
\text { Coefficient }\end{array}$ & 0.123 & 0.126 & $0.293^{* *}$ & 1.000 & & & & & \\
\hline & P-Value & 0.231 & 0.223 & 0.004 & & & & & & \\
\hline \multirow[t]{2}{*}{ Career Planning(CP) } & $\begin{array}{l}\text { Correlation } \\
\text { Coefficient }\end{array}$ & $0.396^{* *}$ & $0.159^{*}$ & $0.536^{* *}$ & $0.267^{* *}$ & 1.000 & & & & \\
\hline & P-Value & 0.000 & 0.040 & 0.000 & 0.009 & & & & & \\
\hline \multirow[t]{2}{*}{$\begin{array}{l}\text { Employee } \\
\text { Participation(EP) }\end{array}$} & $\begin{array}{l}\text { Correlation } \\
\text { Coefficient }\end{array}$ & $0.233^{*}$ & $0.278^{*}$ & $0.385^{* *}$ & 0.071 & $0.312^{* *}$ & 1.000 & & & \\
\hline & P-Value & 0.049 & 0.018 & 0.001 & 0.552 & 0.008 & & & & \\
\hline \multirow[t]{2}{*}{$\begin{array}{l}\text { Performance } \\
\text { Appraisal(PA) }\end{array}$} & $\begin{array}{l}\text { Correlation } \\
\text { Coefficient }\end{array}$ & $0.354^{* *}$ & $0.161^{*}$ & $0.618^{* *}$ & $0.398^{* *}$ & $0.508^{* *}$ & $0.293^{*}$ & 1.000 & & \\
\hline & P-Value & 0.000 & 0.038 & 0.000 & 0.000 & 0.000 & 0.013 & & & \\
\hline \multirow[t]{2}{*}{ Training(T) } & $\begin{array}{l}\text { Correlation } \\
\text { Coefficient }\end{array}$ & 0.078 & 0.072 & $0.278^{* *}$ & 0.164 & $0.221^{* *}$ & 0.022 & $0.337^{* *}$ & 1.000 & \\
\hline & P-Value & 0.352 & 0.394 & 0.001 & 0.109 & 0.008 & 0.854 & 0.000 & & \\
\hline \multirow[t]{2}{*}{ Compensation(c) } & $\begin{array}{l}\text { Correlation } \\
\text { Coefficient }\end{array}$ & $0.300^{* *}$ & $0.182^{*}$ & $0.479^{* *}$ & 0.080 & $0.417^{* *}$ & 0.072 & $0.368^{* *}$ & 0.113 & 1.000 \\
\hline & P-Value & 0.001 & 0.047 & 0.000 & 0.436 & 0.000 & 0.548 & 0.000 & 0.221 & \\
\hline
\end{tabular}

The above tables displays inter correlations among the variables representing the different HRM practices namely general climate, OCTAPACE culture, selection, job definition, career planning, employee participation, performance appraisal, training and compensation. It is clear that the respondents are agreeing that these practices are well established in the organizations under study. These results can be considered as a good sign that different HRM practices are communicated and recognized by both managers as well as subordinates of HDFC Bank. It can be concluded that the results confirm positive relationship between HRM practices that indicates the level of satisfaction of employees towards HRM practices as hypothesized with varying degree of correlation.

\section{SUMMARY OF FINDINGS AND CONCLUSIONS}

On the whole we found the existence of good HRM practices in the sample study organization. The managers in general showed a favorable attitude towards HRM practices in the sample study organizations. They were satisfied with the developmental policies of the top management as well as happy with the prevailing HRM climate in the sample organizations. However, findings of the present study indicate that there is still substantial scope for improvement in various aspects of HRM practices in the sample study organizations. 


\section{SUGGESTIONS AND THE POLICY IMPLICATIONS}

The research study attempts to analyze the impact of HRM practices by focusing on relationship between HRM practices variables on organizational performance in the banking sector within the Jammu and Kashmir state of India. The key to the success of any organization lies in how efficiently and effectively the organizations can manage its assets i.e. human resources. The principle applies equally and perhaps more aptly to service institutions like banks. The banking industry in India, which is working hard to cope up with the technological changes and meets the challenges of globalization. In the developed countries the modern and sophisticated technology is widely accepted in the banking industry, while in India especially Jammu and Kashmir has to go long way for having perfectly managed banks.

As for as banking industry is concerned there is no other input except human resource and the output depends entirely on the quality of human resource and we have lot of factors to cover in this area. Various HRM practices have been acquired in Indian banking industry through a very gradual and reactive process. Since these practices have been acquired at different stages, they are neither cohesive nor complementary and may not be in a line with the current business activities and expected future diversification. The need of the time is not the routine casual and gradual approach but to be proactive, well planned, instant and multi prolonged approach to cope with the various challenges like unpredictable technological development, competitive environment, diversified composition of human resource, increasing expectation of customers , effects of financial reforms within the country and globalization. Given these realities, the banks are under tremendous pressure to initiate new approaches, takes efforts to sustain these initiatives and a higher degree of professionalization of HRM function, which in turn calls for the paradigm shift in managing human resources in banking industry in India .

\section{LIMITATION AND DIRECTION FOR FUTURE RESEARCH}

The research study made number of limitations. The main limitation of this research study is about sampling issue as the small sample size reported may have affected the research results. Even our research findings might have depicted certain results these findings cannot be construed as an independent model to ensure performance of the organizations. Nonetheless, this model has provided insight into possible reasons for organizational performance. In addition to that, the study focused on perceptions of organizational performance and HRM practices as reported by the employees. Hence it is subject to common source and common method bias as perception varies from person to person. The study did not cover all the HRM practice variables that have an impact and relationship with organizational performance.

Several suggestions and recommendation that are fruitful for future research emerged from this present study. In order to validate the findings of the study, case study, focus groups and longitudinal studies are another interesting approach that can be undertaken for future research. Additionally, the research model of this study can be tested in other service sector like education, hospitals and tourism with the large sample size so that the research model can be generalized.

\section{References}

Ahmad, R. and D.P. Spice, (2000). Practice of performance appraisal in the Malaysian Public service: Proposal for research exploring the cognitive processing model. Paper Presented at the First Symposium on Graduate Management Research, University of Malaysia, Kedah Darul Aman, pp. 15-16.

Ali, T. and N. Akter (2011). Performance appraisal system and its practices on local private business organisation of Bangladesh. Inform. Bus. Rev. J., 2(4): 173-180.

Alphonsa, V.K, Sr. (2000). HRD Climate in a Private Hospital in Hyderabad-An Empirical Study, IJTD, Vol. XXX(4). 
Armstrong, M. (2001). A Handbook of Human Resource Management Practice, Kogan Page, $8^{\text {th }}$ Ed.

Armstrong, M. and Brown, D. (2005). Relating Competences to pay: The UK Experience, Compensation and Benefit Review, 18(2): 2905-310.

Aswathappa, K. (2000). Human resource and Personnel Management”, Tata Mcgraw-Hill Publishing Company Limited, New Delhi.

Balkin, David B., and Luis R. Gomez-Mejia (1987). A Contingency Theory of Compensation Strategy. Strategic Management Journal, 8: 169-182.

Barney, J. (1991). Firm Resources and Sustained Competitive Advantage. Journal of Management, 17(1): 99-120.

Bartel, A. P. (1994). Productivity gains from the implementation of employee training programs. Industrial Relations, 33(4): 411-425.

Bartol, K.M. and E.A. Locke, 2000. Incentives and Motivation. In: Sara, L.R. and G. Barry, (Eds.), Compensation in Organizations: Current Research and Practice. Jossey Bass, San Francisco, pp. 104-147.

Becker, Brian and Gerhart, Barry, (1996). The impact of HRM on or gl. Performance: Progress and prospectus, Academy of Mgt. Journal, 39(4): 836-866.

Bhardwaj, G. and Mishra, P. (2002). Human Resource Development Climate: An Empirical Study among Private Sector Managers, Indian Journal of Industrial Relations, 38(1): 66.

Bob, N. (2011). Making employees suggestions Count, Journal of Personnel Management, 17: 20 -41.

Brown, M. and J.S. Heywood, (2005). Performance Appraisal Systems: Determinants and change. B. J. Ind. Relat., 43(4): 659-679.

Carl F. Fey (2000). The Effect of Human Resource Management Practices on MNC Subsidiary

Chand M. and Katou A. (2007). The Impact of HRM practices on organizational performance in the Indian hotel Industry, Employee Relations, 29(6): 576-594.

Cowling, A. and Newman, K. (1995). Banking on People. Personnel Review, 24(7): 25-41.

Davies, F., Moutinho, L. and Curry, B. (1995). Construction and testing of a Knowledge-based system in retail bank marketing. International Journal of Bank Marketing, 13(2): 235-260.

Dawes, J. and Swailes, S. (1999). Retention sans frontiers: Issues for financial services retailers. International Journal of Bank Marketing, 17(1): 36-43.

Denisi and Griffin (2005). Human resource management (2rd ed.). USA: Houghton Mufflin Company.

Flippo, E.B. (1984). Personnel Management, Sixth Edition, New York, McGraw-Hill Book Company.

Gerhart, B. and Milkovich, G. T. (1990). Organizational differences in managerial compensation and financial performance. Academy of Management Journal, 33: 663-691.

Hanley, G. (2005). Right on the money: What do Australian unions think of performance-related pay? Employee Relat, 27(2): 141-159.

Harrison, D.A and Liska, N. (2010). Promoting Regular Exercise in Occupational Fitness Programme, Journal of Personal Psychology, 5(5): 27-45.

Hayes, D. K. and Ninemeier, J. D. (2009). Human resource management in the hospitality industry. New Jersey: John Wiley and Son Inc.

Heller, F., Pusic, E., Strauss, G. and Wilpert, B. (1998). Organisational Participation: Myth and Reality, Oxford: Oxford University Press.

Huselid M. A. (1995). The Impact of Human Resource Practices on Turnover, Productivity, and Corporate Financial Performance, Academy of Management Journal, 38: 635-672.

Hussain-Ali, M.A.M. and H.H.D.N.P. Opatha (2008). Performance appraisal and business performance: An empirical study in Sri Lankan apparel industry. SriLankan J. Hum. Resour. Manage., 2(1): 74-90.

Hyde, Jeffrey, Richard Stup and Lisa Holden, (2008). The Effect of Human Resource Management Practices on Farm Profitability: An Initial Assessment. Economics Bulletin, 17(12): 1-10. 
Jackson, S. E., Schuler, R. S. and Rivero, J. C. (1989). Organization characteristics as predictors of personnel practices. Personnel Psychology, 42: 727-786.

Joseph K. E and Dai. C. (2009). HRM Practices and Organizational Performance: An Empirical Analysis, International Journal of Business and Management, 4(8):117-127.

Khatri N. (1999). Emerging issues in Strategic HRM IN Singapore, International Journal of Manpower, 20(8): 516529.

Kumar, N. Rajendre. (1997). An Investigation into the Contribution of training, Towards HRD Culture/ Climate/ Values in a Public Sector Organisations, IJTD, XXVII, (3).

Kumar, Sharad and Patnaik Sabita. P. (2002). HRD Climate and Attributes of Teachers in JNVS, IJTD, XXXII, (2): 3137.

Lado .Augustine A. and Mary C. Wilson (1994). Human Resource Systems and Sustained Competitive Advantages: A Competency Based Perspective, Academy of Management Review, 19: 699-727.

Lee, Feng-Hu and Lee, Fzai-Zang (2007). The relationships between HRM practices, Leadership style, competitive strategy and business performance in Taiwanese steel industry, Proceedings of the $13^{\text {th }}$ Asia Pacific Management Conference, Melbourne, Australia, 953-971.

MacGregor, D. (1960). The Human side of Enterprises. New York; Mcgraw Hill.

Manolescu, A. (2003). Human Resource Management, 4th Edition, The Economic Publishing House, Bucarest, p.332

Millward, N., Bryson and J. Forth (2000). All Changes at Work? British employment relations 1980-1998, as portrayed by the Workplace Industrial Relations Survey, Routledge, London.

Mishra Prashant, Dhar Upinder and Dhar Santosh, (1999). Job satisfaction as a crrelate of HRD climate (An Empirical Study), 1JTD xxix(2).

Nayyab H. H., Hamid M., Naseer F. and Iqbal M. (2011). The Impact of HRM practices on the Organizational performance :The study of banking sector in Okara, Punjab Paki stan)", Interdisciplinary Journal Of Contemporary Research In Business, 3(3): 661-672.

Newstrom and Davis (2004). In Bhuiyan, M.H (2010). Employee Participation in Decision Making in RMG sector of Bangladesh: Correlation with Motivation and Performance. Journal of Business and Technology (Dhaka) 5(2): $122-132$.

Osman I., Ho T.C.F. and Galang M. C. (2011). The relationship between human resource practices and firm performance: an empirical assessment of firms in Malaysia, Business Strategy Series, 12(1): 41-48

Parasuraman, A., Zeithaml, V. A. and Berry, L. L. (1988). Servqual- A multiple-item scale for measuring consumer perceptions of service quality. Journal of Retailing, 64(1): 12-40.

Pearce, L. (2010). Managerial compensation based on organization performance, Journal of Industrial Relation, 52:3-28. Performance in Russia, SSE/EFI Working Paper Series in Business Administration 6.

Pynes, J. E. (2009). Human resources management for public and nonprofit organizations: A strategic approach. USA: A Wiley Imprint.

Qureshi M. Tahir and Ramay I. Mohammad (2006). Impact of Human Resource Management Practices on Organizational Performance in Pakistan, Muhammad Ali Jinnah University, Islamabad.

Rao, T.V. and Abraham, E. (1999). Reading in HRD, Oxford and IBH Publishing Co Pvt. Ltd New Delhi.

Rohmetra, Neelu (1998). Towards Creating a Learning Organisations: The HRD Climate Focus, Paradigm, 2(2): 5663.

Rondeau Kent V. and Wager Terry H. (2001). Impact of human resource management practices on nursing home performance, Health Service Management Research, 14(3): 192-202.

Rundle, S.J. (1997). Flexibility, adaptiveness and responsiveness (FAR-ness) as the key success factors in market entry in the south east Asian growth wedge, PhD thesis, Department of Management, Monash University, Victoria. 
Russell, J. S., Terborg, R. S. and Powers, M. L. (1985). Organizational performance and organizational level training and support. Personnel Psychology, 38: 849-863.

Saraswathi, S. (2010). Human resources development climate: An empirical study. Int. J. Innovat. Manage. Technol. 1(2): 174-179.

Shafritz, J.M, Russell, F.W, and Borick, C.P. (2007). Introducing Public Administration, (5th Edition) New York Pearson Longman.

Terpstra, D. E. and Rozell, E. J. (1993). The relationship of staffing practices to organizational level measures of performance. Personnel Psychology, 46: 27-48.

Tim Hannagan (1995). Management Concept and Practices, Harlav, Essox Pitman Publishing.

Tracey, W.R. (1998). The human resources glossary, 2nd ed. Boca Raton, FL: St. Lucie Press.

Wagner, J. A. and Gooding, R. Z. (1987). Effects of societal trends on participation research. Administrative Science Quarterly, 32: 241-262.

Wright, P.M., MacMahan, G.C. and MacWilliams A. (1994). Human Resource and Sustained Competitive advantage: A resource based perspective, The International Journal of Human Resource Management, .5(2): 302-26 